\title{
Mobility, Economic Strategies, and Social Networks: Investigating Movement in the Mewar Plain of Rajasthan
}

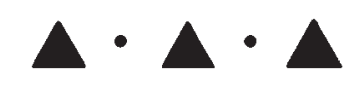

TERESA P. RACZEK

\section{INTRODUCTION}

Most of HUMAn history in South Asia has been a mobile one. It is only around 7000 B.C. at Mehrgarh (C. Jarrige et al. 1995; J.-F. Jarrige et al. 2005), and later in more southern regions, that people settled down into permanent habitations. Even with the onset of sedentism, though, many people continued to practice a mobile lifestyle in concert with a variety of subsistence strategies including foraging, pastoralism, craft production, and performance. Many archaeologists who study early farming communities and early complex societies in South Asia have identified connections between sites occupied by mobile groups and more permanent settlements. In contrast to this type of research, which studies mobile people through the lens of sedentism, I present here a study of the practice of mobility that focuses on the direction, range, and patterns of movement of the people who inhabited the site of Bagor (c. 5500 B.C.-A.D. 200). While the connections between the temporary occupation of Bagor and nearby permanent settlements have been well documented, the movements of the Bagor occupants have been less well studied. In this article, I use new survey data and examine the raw materials used at Bagor to determine the direction, extent, and range of movement of the site's occupants. Examining these different aspects of mobility provides important context for understanding broader practices linked to mobility, including the pursuit of economic strategies and engagement in social networks.

Mobility is a practice that enhances particular subsistence strategies, but should be considered separately from subsistence (Jacobson 1975; Kelly 1992; Wendrich and Barnard 2008). For example, the practice of transhumance among pastoralists allows the keepers of livestock to adequately feed their flocks year-round, while simultaneously opening up new markets for selling livestock and secondary products. Among craft producers, mobility ensures direct procurement of raw materials and a steady supply of customers in need of pedaled crafts. Similarly, by regularly shifting residence, performers can continuously encounter new audiences ready for entertain-

Teresa P. Raczek, Ph.D., is an Assistant Professor in the Department of Geography and Anthropology, Kennesaw State University, Kennesaw, Georgia, U.S.A. 
ment. For these reasons, many communities in South Asia have practiced a degree of mobility through the twentieth century and to some extent in the present day.

It should be cautioned that in many ways the sedentary-mobile dichotomy is somewhat misleading (Binford 1980; Kelly 1992; Wendrich and Barnard 2008). Farmers leave the village regularly as part of daily work and social routines. They also make seasonal trips for hunting, resource acquisition, ritual performance, exchange, and social interaction. Pastoralists and foragers also range in their degree of mobility and may shift camp on a daily basis or as little as once a year. Mobility may split a community for a period of time, as segments move in different directions. Alternatively, at times, entire communities may move together as a single group. These patterns may change in response to drought or environmental concerns as well as disease, warfare, and extra-annual religious or social cycles. Mobility and sedentism should be considered on a continuum; all human groups use a diverse strategy that varies from day to day and year to year. For these reasons, it is difficult to study mobility directly in the archaeological record (Close 2000).

Numerous archaeological examples of interaction between highly sedentary and highly mobile people in the first few millennia B.C. through historic periods have been documented in South Asia (Allchin 1977; Cooper 1997; Meadow and Patel 2002; Morrison 2002c; Possehl 1979; Rissman and Chitalwala 1990; Selvakumar 2002). The most notable examples include the pastoral camps near Harappa and the site of Langhnaj near Lothal. At these sites the presence of metal artifacts, distinctive pottery, or beads, provide evidence of interaction.

Evidence in the Indus suggests that the inhabitants of farming settlements and cities interacted regularly with nomadic pastoralists. Mughal (1994) argues that immediately prior to the Early Harappan, most settlements in Cholistan, an arid region, were camps of nomadic pastoralists. While the percentage of pastoral camps declined in the Early Harappan period, they rose again in the Mature and Late Harappan periods, when they comprised about 26 percent of all known sites (Mughal 1994:60). Mughal hypothesizes that the pastoralists may have provided meat, secondary animal products, services, and transportation to occupants of the permanent settlements. Pastoral camps that are contemporaneous with farming settlements have also been identified in Gujarat (Bhan 1994, 2011; Madella et al. 2010; Patel 2009; Possehl 2007). Guha (1994) argues that in addition to pastoralists, the contribution of hunter-gatherers to the overall Indus economy should not be underestimated or ignored. Thus, in the Indus region, there is ample evidence for high degrees of mobility among some groups that simultaneously remained integrated into broader Indus society.

In Gujarat, the temporary settlement of Langhnaj is located near the Indus trading center of Lothal, a town that engaged in high levels of intraregional and interregional trade (Possehl 1976; S. R. Rao 1979). Langhnaj was occupied by "hunter-fisher folk" in the third millennium B.C. (Sankalia 1965:8). While no architectural remains were detectable at this site (IAR 1953-1954, 1963-1964; Sankalia 1955, 1965), thousands of lithics were retrieved (Leshnik 1974; Sankalia 1965:28-32; Zeuner 1952), along with ten species of wild animals (Clutton-Brock 1965). Three major classes of artifacts are presumed to have been acquired from nearby farming villages and towns like Lothal. These include a copper knife, distinctive black and red ware pottery, and beads that resemble Harappan disk beads (Sankalia 1965:19). Sankalia argues that, "The occurrence of bits of pottery with burnished black interior and red slipped exterior suggests that the microlithic man of Langhnaj had established contacts with 
cultures using this pottery — such as Saurashtra, Rajasthan and the Deccan" (Sankalia $1965: 17)$. He also suggests that "The copper knife again should be an import from Rajasthan, probably eastern Rajasthan, or made from the ore from this region" (Sankalia 1965 :19). Artifact typologies, site location, and the small scale of manufacturing all indicate that the occupants of this and similar sites in the North Gujarat Plain collected several raw materials used in craft production and export at Lothal (Possehl and Kennedy 1979:593). While evidence of such artifacts was not retrieved from Lothal, it is possible that the inhabitants of Langhnaj provided goods that do not leave a trace in the archaeological record or that are not necessarily identifiable as imports (such as meat, baskets, rope, honey, wax, etc.; see Fox 1969).

Studies of the 14 human burials at Langhnaj provide additional evidence to support the idea of exchange with sites like Lothal (Ehrhardt and Kennedy 1965; Karve and Kurulkar 1945; Karve-Corvinus and Kennedy 1964; Walimbe and Kulkarni 1993). While the teeth of one skeleton were quite worn from a coarse diet, another skeleton had dental caries (Ehrhardt and Kennedy 1965:46). Worn teeth are expected among hunting and gathering populations; however, dental caries are less common and indicate that the inhabitants had a mixed diet that may have been high in carbohydrates. Lukacs suggests that the dental caries rate of 8.0 percent is much higher than dental caries rates recorded at other sites occupied by hunter-gatherers, and may be caused by the "periodic" consumption of agricultural foods (Lukacs 1990:183). Presumably, these items were obtained through exchange with local farmers.

Possehl has argued that the mobility of the hunter-gatherers of Langhnaj placed them in a unique position to act as traders, bringing forest products into the gateway city of Lothal (Possehl 1993, 2002). Thus, mobility served to support both economic strategies and the formation of social networks. Archaeological studies demonstrate that mobility was practiced in the first few millennia B.C. in Gujarat (Ajithprasad 2002; Possehl 2007; Swayam 2006; Varma 1991) and throughout South Asia (Leshnik 1972; Panja 1996, 1999; Possehl 1979; Selvakumar 2002) in concert with a range of economic strategies including foraging and pastoral subsistence strategies, and potentially other economic activities. That mobility fostered interactions with those who lived more settled lifestyles has been demonstrated through analysis of crafts, food remains, and human skeletal remains.

\section{ETHNOGRAPHIC ANALOGIES}

Extensive ethnographic research in Rajasthan and throughout South Asia has provided multiple models for explaining a wide range of archaeological patterns, including those related to mobility (Allchin 1985; Chase 2004; Mohanty and Mishra 2002; Sinopoli 1991). Ethnographic analogies must be applied carefully in part because modern historical developments have greatly influenced mobility patterns observed by ethnographers. A direct historical link between contemporary mobile groups of South Asia and those of the archaeological record should not be assumed. Instead, ethnography can lend insight into practices shaped by the geographical and environmental context, which shares some similarities between past and present (Ascher 1961). Although there are difficulties in using ethnographic analogy (Gould and Watson 1982; Yellen and Harpending 1972), it remains a critically useful tool. Ethnographic analogy best works when a full consideration of multiple points of connection and distinction are considered as well as the relevance of identified correspondences (Wylie 2002). In this 
case, I use ethnography to highlight the range of social practices associated with mobility, as well as the variation of mobility practices themselves.

Historically, many groups in South Asia have practiced temporary, seasonal, or continuous mobility in concert with pastoralism (Fisher 1997; Kavoori 1999). Gujarati pastoralists have sometimes traveled north into southeastern Rajasthan during their annual migrations (Swayam 2006). Both Rajasthani and Gujarati pastoralists have been well integrated into their home villages. In addition, they form vast networks with other pastoralists, farmers whose land they traverse, and merchants who buy their products (Childers 1975, 2003; Sontheimer 1975).

Ethnographic research on hunter-gatherers in South Asia has also identified a number of different mobility patterns as well as a range of social and economic ties with nearby villagers (Morrison 2002c). For example, in contemporary times, some hunter-gatherer groups lived in hill regions because much cultivable land had been claimed and developed by villagers and hill slopes were largely unsuitable for agriculture (Hockings 1989; and see Morrison 2002b). Therefore, hill land was occupied by foraging groups who had historical claims to the area as well as by those who were marginalized from farming communities and who sought alternative means of subsistence. Many hunter-gatherers also produce crafts and provide services (e.g., Nagar and Misra 1990). In Rajasthan, the Bhils (Hooja 1994; Murty 1994), Van Vagaries (V. N. Misra 1990), and Bawaria (Dutt 2004) are examples of such groups. Economic interactions between separate communities who specialize in distinct economic niches affect mobility strategies. A wide variety of mobility and subsistence activities have been undertaken by contemporary foragers and groups whose history includes episodes of foraging. It is important to understand the particular historic context in which particular foraging groups are situated, including an examination of regional power dynamics (Morrison 2002a).

Other highly mobile groups include artisans who focus exclusively or mainly on the production of crafts or the provision of services (such as entertainment and religious services), although they may also hunt, gather, or tend a few animals on the side. Like other nomadic or semi-nomadic groups, peripatetics including entertainers, medicine specialists, tinkerers, or traveling salesmen also keep to seasonal migrations (A. Rao 1987:4). In Rajasthan, the Gadulia Lohars are nomadic iron workers who travel between villages repairing and fabricating iron implements for use by villagers (P. K. Misra 1975, 1977). They frequently pitch camps on the edges of villages and towns.

In addition to demonstrating a range of economic strategies associated with mobility, ethnography has also documented a range of relationships that exist between highly mobile and highly settled groups. Transhumant pastoralists are often tightly integrated into their home village and seasonally embark on migrations in order to feed their flocks. During these migrations, pastoralists settle into temporary camps, some of which they re-use on an annual basis. Thus, they build additional social ties to villages where they camp during their annual migrations and with the families on whose land they camp (Swayam 2006). Hunter-gatherers, on the other hand, have historically lived as separate communities that interacted with villagers in order to trade forest products, crafts, or labor for farm goods and crafts. Traveling artisans and service providers have also had looser ties to the villages where they encamp and in contemporary times have been viewed frequently with suspicion or fear by villagers (Hayden 1987:270). Helms (1993) has argued that fears of those who are "travelers" 
by occupation are associated with fear of the "outside," or areas that are at some geographical distance. Just as the outside is associated with the unknown, wildness, and chaos, "travelers" are regarded as dangerous, magical, and powerful.

In sum, multiple economic strategies and social relationships are linked to mobility. Both economic and social considerations affect the scheduling of movement as well as the distance traveled and the regions in which travel occurs. Shifts in economic or social conditions may precipitate corresponding shifts in mobility. Tracing these archaeologically visible patterns provides additional insight into the life of mobile groups beyond identification of exchange.

\section{MOBILITY AND LITHICS}

Lithics are an excellent resource for studying mobility because they are composed of raw materials that can sometimes be identified and sourced visually. Lewis Binford (1979) argued that the chore of raw material procurement is most efficiently accomplished in the course of regular movements. As a result, raw material procurement is embedded in the routines of mobile people who are more likely to select materials encountered in currently used paths. Sometimes special trips are made to collect raw materials based on factors like raw material quality (Gould and Saggers 1985) and a decrease in raw material quantity at regularly used sources (Dibble 1991). Some lithics may be considered to hold special spiritual powers or meaning, which can create an incentive to make a special trip to a source or, alternatively, to avoid certain source areas (Gould and Saggers 1985).

Raw material acquisition strategies and mobility affect lithic production (Dibble 1991; Geneste 1985; Marks et al. 1991). High quality raw material that is procured from far-away sources may be used more intensively, or reserved for specific tools. Good cores made of hard-to-obtain high-quality raw material are often used and rejuvenated until it is no longer possible to retrieve any blades from them. When raw material is plentiful and located nearby, individual pieces may not be used as intensively and are more likely to be thrown away after a few flake or blade removals. The quantity and quality of locally available raw material also greatly influences the kinds of products found in a lithic assemblage (Andrefsky 1994; Brantingham et al. 2000). As Bagor is located near abundant resources of poor-quality quartz and far from goodquality chert and chalcedony, the types of lithics found in the lithic assemblage are similarly affected.

Levels of mobility also affect distribution of raw material within an assemblage since sedentary people do not always have regular access to quarries. Sometimes sites are located near excellent sources of stone, but when this is not the case, arrangements must be made to acquire stone through other means. In many societies stone was procured through exchange. This is true for societies in stone-poor regions like some parts of the Indus, where lithics were procured through trade and exchange (Bhan et al. 2002; Biagi and Cremaschi 1990; Law 2005a, 2005b; Law and Baqri 2003), and effectively turned into commodities.

While levels of mobility affect the presence and amount of a raw material within a lithic assemblage, and the products made from that raw material, they also influence the collection of non-stone raw materials used in tool production, like copper. This consideration is important at Bagor, which utilized copper implements (Raczek 2010b). In many cases, copper can take the place of a stone implement, although this 
technological transition during the early days of copper was by no means universal or straightforward (see, for example, Bayman 2003; Carmody 2003; Johnson 1997; Odell 2003; Rosen 1984, 1996, 1997; Silliman 2003).

Since all of these factors influence lithic production and lithic assemblages, it is possible to read lithics to determine mobility levels and direction and range of movement. By mapping the raw material sources, regions that were traversed or avoided become clear. The location of raw material sources used by the occupants of a given site indicates not only migration in that direction, but integration into social networks in that area as well.

\section{BAGOR}

The site of Bagor in southeast Rajasthan was occupied for over five millennia (5500 B.C. to A.D. 200). While the initial occupations preceded the earliest known permanent settlements in the region, the spot continued to be used intermittently for over three millennia after the first farmers put down roots in the area. The scant remains left at the site suggest that, for much of its occupation, the site was used as a temporary camp by itinerant peoples who practiced a broad range of subsistence strategies that shifted over time. Although a high degree of mobility was evidently practiced by the occupants during most periods, the range of movement was previously unclear. This gap in our understanding is due in part to the paucity of excavations of similar microlithic scatters in the region. Most excavations from this region focus on large sites with extensive settlements. Bagor stands alone as an excavated and well-published microlithic scatter. Although the links between Bagor and nearby permanent settlements have been clearly demonstrated, the question remains: How far did the occupants of Bagor range in their movements, and did the direction or extent of their travels change over time? The answers to these questions can indicate shifts in occupation or subsistence strategies as well as changes in social ties to regions or individual sites. In order to pursue this line of research, I undertook a study of the lithics from the 2001 re-excavations of Bagor conducted by Deccan College (Deshpande et al. 2006; Shinde 2010). My analysis emphasized raw materials and lithic attributes because detailed attention to these features provide great insight into the mobility patterns. In addition, I undertook a targeted survey of stone material sources in order to begin to map the range of the occupants of Bagor.

Originally excavated by V. N. Misra (IAR 1967-1968, 1968-1969, 1969-1970; V. N. Misra 1971, 1973, 1982), Bagor is located on a fossilized sand dune on the banks of the Kothari River. Although the site appears to be a lithic scatter on the surface, the artifact deposition extends over one and a half meters below the surface and includes other artifacts as well as several burials. The earliest inhabitants relied mainly on hunting and gathering, although later occupants also consumed domesticated fauna and plants. Misra divides the occupation of Bagor into three phases (V. N. Misra 1973, 1982):

$\begin{array}{ll}\text { Phase III } & 600 \text { B.C-A.D. } 200 \\ \text { Phase II } & \text { 2800-600 B.C. } \\ \text { Phase I } & 5000-2800 \text { B.C. }\end{array}$

The site has no permanent architecture, although schist stones uncovered in Phase I and II layers appear to have been procured from across the river and served as the foundation for temporary structures. The majority of artifacts in all phases consisted 


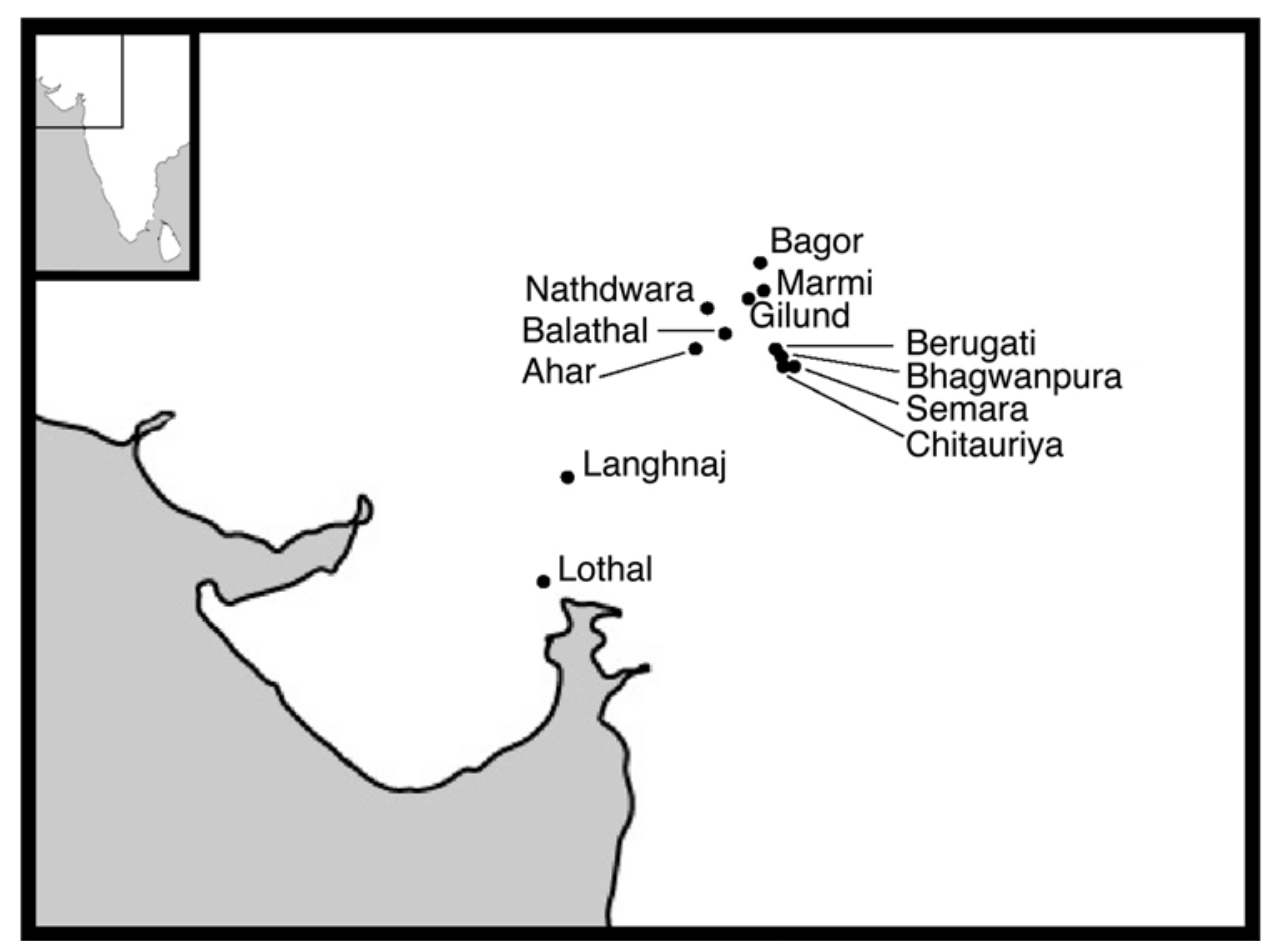

Fig. 1. Location of sites mentioned in text and raw material sources identified through survey.

of bones and lithics. Phase I is largely considered to be aceramic, although some isolated small pieces of eroded pottery were found in these levels (V. N. Misra 1973:100). In addition to pottery, hammerstones, groundstones, two perforated stones, and a spindle whorl were also found in Phase II (V. N. Misra 1973:105).

Five burials were recovered (V. Kumar 1970-1973; V. N. Misra 1972); one is from Phase I, three are from Phase II, and one is from Phase III (Kennedy 1982). No burial goods are associated with the Phase I burial; although several pots were buried with the deceased in Phase II along with copper arrowheads and a stone and bone bead necklace (V. N. Misra 1982). The skeletons were poorly preserved. One of the Phase II skeletons had very bad dental caries, indicating that carbohydrates were consumed regularly (Lukacs 1982:81-82). This suggests that the inhabitants of Bagor may have been either growing cereals or obtaining them from nearby farming settlements, a find supported by Kashyap (2006 and see below). Although biological distance studies were attempted with the Bagor skeletons, the poor preservation of the bones prevented a full metrical and morphological analysis (Kennedy 1982:34). The only other contemporaneous skeletons that have been recovered in the region are five skeletons from Balathal. It is not possible to determine the biological relationship between the Bagor and Balathal skeletons as paleodemogaphy or biodistance studies were not conducted on the Balathal collection due to their small sample size (Robbins et al. 2007). As a result, the biological relationship between the occupants of Bagor and those of other sites in the region remains unclear. 
Vast quantities of faunal remains were recovered from Bagor; however, most were fragmentary. The main faunal analysis indicated that domesticated animal remains including sheep/goat, cattle/buffalo, and pig were present in all three phases of occupation, as were wild animal remains (Thomas 1975, 1977, 1984). As archaeologists have learned more about the bone structure of the local wild animals of Rajasthan, this faunal analysis has been challenged (Meadow and Patel 2002). However, an ongoing re-analysis of the bones utilizing new comparative collections suggests that, as Thomas noted, wild and domestic animals are mixed throughout the occupation levels (Matthew Landt, pers. comm.). Thus, the subsistence strategies of the inhabitants appear also to have been mixed, with both hunting and herding activities regularly occurring.

Microwear studies on the lithics from Bagor suggest that some blades were used in plant processing (Kashyap 2006; Khanna 1988). In addition, Kashyap's study of starch grains recovered from the lithics indicates that the inhabitants prepared and consumed a variety of fruits, pulses, and grains, both wild and domesticated (2006). Thus it appears that the inhabitants of Bagor during later time periods may have produced plant foods in addition to gathering them. It is also possible that the previously documented exchange relationships between Bagor and Ahar-Banas and Harappan sites (V. N. Misra 1970) may have included food products. Such exchange of food products between farmers and either hunter-gatherers or pastoralists has been documented in several regions outside of South Asia (Adams 1974; Alizadeh 2009; Khazanov 2009; Nelson 1973; Peterson 1978; Spielmann 1986). The extent to which the occupants of Bagor may have undertaken agricultural activities has great relevance for their mobility patterns. Growing crops would have required at least a part of their community to remain at the site during the growing season. If these practices were adopted, mobility patterns would have shifted substantially. Such shifts would also have impacted social ties to distant regions if mobility was substantially reduced or migration was limited to select members of society.

Misra thoroughly analyzed the lithics from the original excavations at Bagor, focusing on typology and basic raw material classification. Although he did not discuss the source of the chert and chalcedonies, he found that the quartz was procured locally and wrote, "Quartz and chert were the most common raw materials used and although quartz predominates in the waste material because of its intractable nature, the majority of the finished tools are of chert. The greater use of quartz was no doubt due to its ready availability in large veins in the schistose rocks just across the river" (V. N. Misra 1973:96). Quartz is also available in numerous other locations within $1 \mathrm{~km}$ of Bagor and throughout southwestern Rajasthan. The source of the chert and chalcedony was unclear at the time, something that would have helped indicate mobility patterns.

An attempt to delineate mobility patterns of the occupants at Bagor was first conducted by Gurcharan Khanna (1992, 1993), who specifically looked at chalcedony procurement. His analysis of a lithic sample from the original Bagor excavations revealed that some tool types were made disproportionately out of chalcedony. He further observed that chalcedony tools tended to be smaller than those made of other raw materials (mostly quartz and chert). He therefore argued that chalcedony was preferred for the manufacture of small tools due to its excellent flaking qualities, and that it was specifically procured for that purpose. The preferred use of high-quality chalcedony over locally available poor-quality quartz would have had two effects. 
First, chalcedony would be made to last as long as possible and would be discarded quite far from its source. Second, chalcedony cores would have been used and retained even when they became extremely small, whereas comparable size cores in larger grained materials, like quartz, may have been discarded before they reached such a small size. The resulting products made from chalcedony would have been quite small compared to more locally procured materials. Although chalcedony was used intensively, it is likely that it was not procured in special material gathering trips, but in the course of movements directed by other purposes such as herding, hunting, etc. (along the lines of Binford 1979).

In order to locate potential chalcedony sources, Khanna examined several geological maps and pinpointed the Deccan Traps, which lie in central India and begin about $90 \mathrm{~km}$ to the southeast of Bagor (1988, 1992, 1993). This study was an important first step toward tracing the movements of the inhabitants of Bagor. Unfortunately, Khanna was unable to field-check his hypothesis, and no further studies on the migratory patterns of the Bagor inhabitants were undertaken until now.

\section{NON-LITHIC EVIDENCE FOR MOBILITY IN THE REGION}

In order to determine mobility patterns, this study examined the lithic evidence. However, prior to this study, two kinds of non-lithic evidence gave some indications to mobility patterns. These include extensive documentation of related microlithic scatters in Rajasthan, Madhya Pradesh, and Gujarat and the presence of exchange goods at Bagor.

Two major surveys in Rajasthan have investigated temporary occupations of the region and have reached some important conclusions regarding mobility. V. N. Misra's survey of the Berach basin (1967) was among the first to recognize and document temporary sites and to observe their frequency as well as their common association with Ahar-Banas white-painted black and red ware. Highly mobile groups would have occupied many of these "camps" during their annual migrations. Following chronologies used at the time, Misra designates the sites as Late Stone Age (LSA) because of the presence of blade and microlithic technology. This technology is similar to that found at Bagor and was used for thousands of years. Unfortunately, without excavation, it is difficult to determine which of these sites are contemporaneous with Bagor and may have been used by the same occupants. Misra argues that the sites he found "are essentially workshop sites where tools were manufactured to be eventually taken to living sites for use" (V. N. Misra 1967:107). This tantalizing clue suggests that there are many useful raw material sources in the region. Although Misra focused specifically on LSA sites, the stone outcrops would have been available in later periods as well.

Hooja's survey also studied temporary occupations in southeastern Rajasthan. She noted that Ahar-Banas white-painted black and red ware and microliths frequently co-occur in simple surface scatters (1988). Here, the discovery of pottery safely dates these sites to the same period as the Phase II occupation of Bagor. Some of the sites may have been occupied by the same inhabitants of Bagor during their annual movements. Hooja argues that the occupants of these surface scatter sites practiced hunting and gathering along with shifting cultivation and that they interacted regularly with their neighbors who emphasized an agropastoral economy. 
Usually interpreted as ephemeral camps, these surface scatter sites represent the temporary occupation of potentially many different groups of mobile people who passed through the region over the millennia. The identification of high numbers of lithic scatters that are contemporaneous with permanent settlements of the AharBanas suggests that mobility was practiced by some communities in that time. These sites range throughout the Mewar Plain, clustering close to water sources, and demonstrate that mobility was also geographically widespread.

In addition to the survey evidence, non-lithic artifacts excavated from the site of Bagor provide insight into the mobility patterns of the occupants. While some of these artifacts point to relationships of trade and exchange, they also index social networks situated within the regions in which the artifacts were made. The artifacts for consideration from the original excavations include pottery, copper objects, and beads.

Phase II pottery from Bagor is generally poorly fired, but resembles regional pottery sequences. Misra compared the pottery to that recovered from Ahar, the only Ahar-Banas site that had been excavated at the time. He argues that while the Bagor pottery is not true Ahar-Banas pottery, the style is the same. He writes:

Some affinities are noticeable between Bagor pottery and that of the Ahar Culture in Mewar ... and of the Kayatha culture in Malwa. . The surface treatment of Bagor pottery is similar to that of the red ware of the Ahar culture though in the latter the red wash has proved to be more durable. Some of the shapes such as the large, shallow basins, deep, straight-sided bowls and the large neckless jar are common to the pottery of the two cultures. In decoration the Ahar pottery (excepting the black-and-red ware) like that of Bagor, is characterized by incised designs, and the motifs found at Bagor are all present at Ahar as well. The presence of a few black-and-red ware sherds at Bagor also provides a hint at some link with Ahar. (V. N. Misra 1973:103)

Sites with Ahar-Banas pottery span a large distance in southeastern Rajasthan and northwestern Madhya Pradesh. Thus, the inhabitants of Bagor may have engaged in social relations in an area of approximately $62,500 \mathrm{~km}$ (a square of roughly $250 \mathrm{~km}$ on a side). As mentioned above, hundreds of similar encampments with microliths or with microliths and Ahar-Banas pottery have been identified throughout this area, confirming the idea that some groups traveled in this area during the second and third millenniums B.C.

In addition to the pottery, a copper spearhead, copper awl, and three copper arrowheads were also found, some of them in Phase II burials (V. N. Misra 1970). Misra suggests that the arrowheads somewhat resemble Harappan arrowheads, which opens up a large geographic range for interaction and potential movement, including areas to the north and northwest. The arrowheads appear to be made of copperbronze that was cut from sheets. A recent visual analysis of arrowheads found in the nearby Ganeshwar-Jodhpura area to the northeast of Bagor and the Ahar-Banas settlements did not find any stylistically similar specimens (Rizvi 2010).

Finally, beads made of bone, agate, and carnelian were found in Phases I and II (V. N. Misra 1973:105). Agate and carnelian are most commonly found in sources in Gujarat. During Bagor Phase II, some sites in Gujarat manufactured great quantities of carnelian beads (Kenoyer 1991; Possehl 1982). The presence of these beads indicates potential interaction with that area, located over $300 \mathrm{~km}$ away. In the case of copper objects and the beads, down-the-line trade is certainly a possibility. However, 
the inhabitants of Bagor were clearly mobile during many phases, and their travels may have extended into Gujarat. Ethnographic research on herders (discussed below) suggests that a range of $300 \mathrm{~km}$ is not impossible. As mentioned above, archaeological survey confirms the presence of similar temporary occupations throughout southeastern Rajasthan, northwestern Madhya Pradesh, and northern Gujarat (Leshnik 1968; Meadow and Patel 2002; Possehl 2007).

Artifactual evidence from excavations and surveys suggest connections between Bagor and far-flung places in many directions. While such evidence does not in itself indicate mobility, it does suggest knowledge of and social connection to these places. Direct procurement is a strong possibility given the temporary nature of the habitation at Bagor.

\section{THE NEW FIELD SURVEY}

In order to assess the direction and range of movement of the inhabitants of Bagor and to detect changes in mobility over time, I conducted a raw material study of the lithics. V. N. Misra's analysis of the Bagor lithics demonstrated that the majority were made of locally available quartz (1973). Khanna later suggested that some Bagor lithics were made of nonlocal materials (1992). My own examination of the immediate area around Bagor located no obvious chert or chalcedony sources. In addition, my examination of the Kothari River bed did not produce any samples of chert or chalcedony. My initial analysis of the Bagor lithics showed that only some of the chert and chalcedony pieces with cortex showed evidence of river-rolling or alluvial turbation. That is, while some of the cherts and chalcedonies were procured from river contexts, many were not. A land-based source must have been used in the majority of the cases. Since no chert or chalcedony deposits were identified in the immediate area, the location of these sources remained unclear. For members of a mobile community like Bagor, it would not be unusual to travel with a "lithic tool kit" (Kuhn 1994) largely comprised of raw materials encountered during the course of each journey (Binford 1979) or through special procurement trips (Gould and Saggers 1985). By identifying the sources of these raw materials it is possible to map areas that the occupants of Bagor may have visited. That is to say, locating chert and chalcedony sources helps in the identification of mobility patterns and ranges. In order to locate potential sources for Bagor lithics, a field survey was conducted in southeastern Rajasthan.

The most common kinds of stone available in southeastern Rajasthan are quartz, chert, and chalcedony. Quartz, which tends to fracture unevenly, is the most abundant of these. While there are different levels of quality in quartz, most of it tends to be difficult to control while knapping. As a result, quartz is frequently a material of last resort for knappers who are making prepared tools of specific shapes. Chert and chalcedony are much easier to manipulate in the process of tool making, and all things being equal are more likely to be favored for the production of particular tools. On the other hand, if the knapper is making expedient flakes and informal tools, quartz is perfectly sufficient and can provide an acceptable sharp edge.

In contrast to quartz, chert fractures in very predictable ways and is an excellent material for blade manufacture (Luedtke 1992). Chert also responds well to heat treatment, which can increase the predictability of fracture. Chert varies in color, translucence, luster, and inclusions and also appears in various qualities. Brecciated cherts, 
common in Rajasthan, are cherts that have decayed somewhat due to exposure to metamorphic pressures. As a result, they tend to have low luster and low diaphaneity, and they do not knap as cleanly as plain chert. In southeastern Rajasthan, chert also appears in a conglomerate form. Here, chert pebbles and rocks combine with quartz and other minerals and under intense pressure form a new rock that also has a concoidal fracture. However, because of the many inclusions, it fractures irregularly. Chert conglomerate is not an ideal material for blade manufacture, but it certainly can work if higher qualities are selected. High-quality chert conglomerate and low-quality quartz are both equally difficult to knap, but can be used to form a wide range of tools, although there will be considerably more debitage and breakage than when using finer materials.

Archaeologists have long used visual analysis to identify chert sources using the qualities mentioned above-color, luster, translucence, and inclusions. However, under certain conditions, the reliability of visual sourcing is lessened. For example, visual sourcing works best when each of the identified lithic sources is comprised of distinct chert varieties (Luedtke 1992). In addition, when sources are located near rivers that transport chert cobbles and pebbles for long distances, then sourcing becomes somewhat of a moot point, because the river serves as a secondary deposit for the material.

Like chert, chalcedony is far superior to common quartz for knapping when the goal is a formal tool. It fractures in very predictable ways and can be heat-treated for greater control. Heat-treating tends to turn chalcedony orange or red, at which point it is known as carnelian (although natural carnelian also occurs in South Asia). While chalcedony has long been popular as a tool material, as mentioned above, it is also popular in the form of carnelian as a material for stone beads. The Harappans in particular are well known for their extensive production and use of carnelian beads in multiple shapes and sizes (Kenoyer 1991; Possehl 1982; Roux and Pelegrin 19881989).

Chalcedony forms naturally in the basalt of the Deccan Traps, a geological formation that spans the center of the Indian subcontinent. The northernmost extent of the basalt can be found on both sides of the border between Rajasthan and Madhya Pradesh. Khanna (1992, 1993) had previously hypothesized that the Bagor chalcedony may have been obtained from the northeastern-most reaches of the Deccan Traps, which extend into this region. Dense deposits of chalcedony in Gujarat were quarried in the first few millennia B.C. for the carnelian bead trade and continue to be heavily used by contemporary bead makers in Khambat (Kenoyer 1991; Possehl 1982; Roux and Pelegrin 1988-1989).

In sum, all three materials found in southeast Rajasthan-quartz, chert, and chalcedony - are useful for making stone tools, including blades and blade tools. Quartz is the least desirable of the three materials because it fractures in uneven and unpredictable ways; however, it is the only material located near Bagor, and it is abundant throughout the region. Chert and chalcedony are much easier to manipulate, especially when manufacturing very small items. Chert and chalcedony also respond well to heat treatment, which means that it is possible to change the way they respond to striking. However, they can only be procured at some distance from Bagor.

Prior to field exploration, several geological maps of the region were studied to identify potential chert and chalcedony sources. These included District Resource 
Map I (Geology and Minerals) for both Rajsamand District and Bhilwara Districts published by the Geological Survey of India, as well as maps presented in Roy and Jakhar (2002) and Gupta et al. (1997). Maps published by the Survey of India indicated the location of lime kilns and provided topographical and other geographical information. United States Army maps for India NG43-14 and NG43-10 were also used. $^{1}$

As I visited each area, I first conducted an informal "field check" in order to assess whether any stone raw materials or artifacts were visible. All sites with both plentiful stone raw materials and evidence of lithic manufacture were more intensively investigated. At each of these areas, transects were walked, raw material samples were gathered, and artifacts were collected from $1 \times 1 \mathrm{~m}$ units. The following stone raw material sources were identified. ${ }^{2}$

\section{Semara (District Chittorgarh)}

Located approximately $105 \mathrm{~km}$ south-southeast of Bagor, the site is a low mesa-like limestone hill that rises behind the village of Semara. It has been identified in the geological literature as having a non-fossiliferous chert bed. Two small shrines are located at the top of the hill as is a collapsed mobile phone tower at the very north end of the hill. The slopes and top of the hill are frequented by goat-herders, and much of the top of the hill is presently under cultivation as are all of the areas surrounding the hill.

The hill is comprised of semi-angular boulders (approximately 1-2 $\mathrm{m}$ in size) and small round cobbles and pebbles. The vegetation consists of some low scrubby bushes and light grass. The chert bed lies about halfway up the hill and varies from approximately 1 to $3 \mathrm{~m}$ in thickness; it is only present irregularly. The chert is mostly in boulder form, although some non-cortical nodules also exist. Red and light brown chert is sometimes found together; browns and creams are also present, as are very translucent varieties. Clear and smoky chalcedony are both found in association with bluish gray chert. Artifacts are mostly located on top of the hill, although some can be found in the vicinity of the chert and below. The presence of an Acheulian hand axe, bifaces, and Levallois cores suggest that the area has been used since the Paleolithic. Evidence of microblade production is also present. In general, the density of artifacts at Semara is quite low; the densest collection areas had about 1-3 artifacts per $\mathrm{m}^{2}$, although there are higher concentrations in other areas.

\section{Bhagwanpura (District Udaipur)}

Bhagwanpura is located about $95 \mathrm{~km}$ south-southeast of Bagor. It is known for its limestone quarry and for the black chert previously identified by Kumar and Srivastava (1992). The chert is present in a large field on both sides of the road, near a village. During the site visit a highly diaphanous chert that ranged from blue-gray to black was identified. A number of microliths were found here as well as blade and flake cores, blades, and other tools (a microburin, a burin spall, and scrapers). While most of these were made of the Bhagwanpura black chert, some were made of light brown and red cherts. 


\section{Chitoriya (District Udaipur)}

Chitoriya is located approximately $10 \mathrm{~km}$ west of Semara and $105 \mathrm{~km}$ south-southeast of Bagor. Red and brown chert can be seen in the fields here, next to a quartz outcrop, on which sits an occupation with stone walls and Early Historic pottery. Much of the site has been destroyed recently by rock and soil borrowing. Microlithic tools, cores (both flake and blade), flakes, and blades were all found, mostly made of the local red and brown chert, although artifacts made of quartz and Bhagwanpura black chert were also found.

\section{Berugati (District Udaipur)}

Berugati is located near Chitoriya, approximately $85 \mathrm{~km}$ southeast of Bagor. It is a small hill range with light brown brecciated chert beds. Pink, red, and cream deposits were also identified as well as a small deposit of blue-black chert boulders near the southern end of the hill. A few dense lithic scatters, some of which had considerable evidence of blade and microlith manufacture, were noted. Blades, flakes, cores (blade and flake), and tools (burins, burin spall, drill, notch-on-flake, and scrapers), were collected. Although blades and blade cores are common at this site, no microlithic tools were observed. In addition, no pottery other than modern sherds was observed. A modern ashram and a shrine are located near the road.

\section{Nathdwara (District Rajsamand)}

Nathdwara is located approximately $70 \mathrm{~km}$ to the southwest of Bagor in the midst of foothills of the Aravalli Mountain range. Sankalia reported a Palaeolithic site in this region (1956). The hills hold abundant limestone that is currently quarried extensively for lime production. Many areas have lost considerable surface area and deforestation has also led to significant erosion of the hills. A very distinctive chert conglomerate was found, in brown, dark brown, and red, on one hill that overlooks the Banas River.

\section{Banas River}

It has long been thought that some lithic raw material used in this region may have come from the Banas River. The river flows in a northeasterly direction and comes as close as $20 \mathrm{~km}$ to the south of Bagor. A search of the riverbed near the sites of Gilund and Marmi produced a few nodules of chert conglomerate that appear identical to that found at Nathdwara and presumably washed down the river from that area. Nodules from Nathdwara cannot travel in the Kothari River because of the direction of water flow.

\section{SURVEY SUMMARY}

In all, five chert sources and one chalcedony source were documented (see Fig. 1). The Banas River also may have served as a source of material in secondary context. Quartz was found to be abundantly available throughout the region as well as across 
the river from Bagor. It should be noted that these deposits were all very small; none of them contained sufficient material to create a sustained quarry for regular stone procurement. Instead, these sites offered passersby the opportunity to acquire a few quick pieces in order to replenish their tool kits. The extent of deposition was limited in each instance, and none of these sources offered sufficient material to sustain a blade-producing industry like that found in the Rohri Hills in Pakistan (Biagi and Cremaschi 1990). In the Rohri Hills, craft specialists created crested cores and blades for export and use in sites like Harappa. However, in southeastern Rajasthan, no such industry developed. Instead, chert and chalcedony were procured by travelers as they passed these small sources of high-quality stone. The reason that travelers passed through this region, then, was not to collect stone raw materials, but to pursue other goals and fulfill other obligations.

The deposits identified were small and highly localized, and the geological maps of the region are not complete for chert. As a result, it is possible that additional chert and chalcedony deposits exist in the region, but were undetected during field survey. Similarly, it has been shown that small sources can be easily depleted and rendered invisible in modern contexts (Dibble 1991). Thus, it may not be possible to identify all sources used by the occupants at Bagor.

\section{RAW MATERIAL ANALYSIS}

The raw material analysis was conducted with the goal of identifying local and nonlocal materials used in the production of lithics at Bagor. The identification of chronological shifts in procurement locations indexes corresponding shifts in mobility patterns. Shifts in mobility patterns in turn may reflect changing economic strategies and occupations such as a turn to farming from pastoralism, foraging, or service provision. Shifts in movement direction can also indicate corresponding changes in social relationships - a deepening of new social relationships in new regions or a weakening or strain of ties to old regions. The majority of the lithics at Bagor were made of locally available high-quality quartz (see Fig. 2). The remainder were made of chert and chalcedony, with a few pieces of quartzite and garnet. ${ }^{3}$ Like quartz, quartzite and garnet are local to the area. However, chert and chalcedony are nonlocal.

In the raw material analysis, artifacts and survey samples of raw material were studied in order to find potential matches between artifacts and sources. A number of raw material attributes were recorded. Chert was examined particularly closely, and both artifacts and chert material samples collected from the field were thoroughly described with an emphasis on the following features: quality, color (identified with the aid of a Munsell rock color chart), translucence, inclusions, mottling, luster, patination, and heat treatment. In the course of analysis a number of chert types were developed in response to observed clusters of attributes. Designations such as "Bhagwanpura Black" were developed as shorthand appellations for constellations of attributes that include color, translucence, luster, inclusions, etc. The type refers to the source where the raw material was found, although it is certainly possible that the type may be found in other as yet unidentified locations.

In all, two creams, four reds, one black, one blue-gray, three brown, and two mixed color cherts were located during survey and were also identified in the collections at 


\section{Raw Material Distribution by Lot Number \\ (Primary Study Sample)}

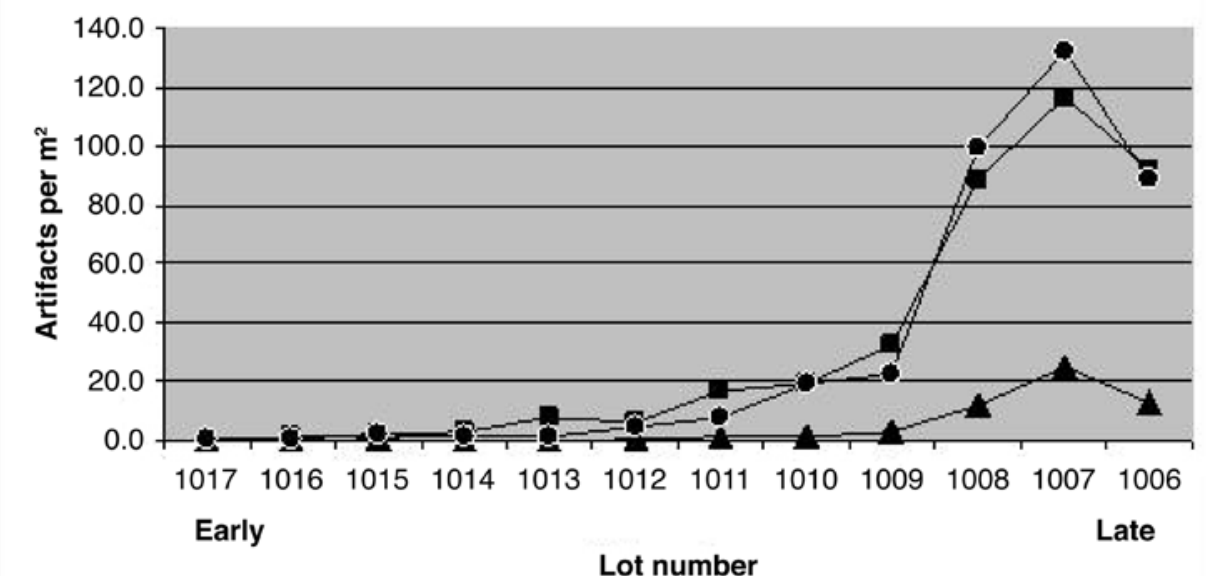

$\rightarrow-Q u a r t z \longrightarrow$ Chalcedony -^-Chert

Fig. 2. Raw material distribution.

Table i. Number of Chert Types Recorded at Each Survey Site

\begin{tabular}{lccccc}
\hline & SEMARA & BERUGATI & BHAGWANPURA & NATHDWARA & CHITAURIYA \\
\hline Pinks & 3 & 2 & & 1 & 1 \\
Reds & 2 & 1 & 1 & 2 & \\
Browns & 1 & 1 & & \\
Blacks & 1 & 1 & & \\
Grays & 2 & 1 & & \\
Creams & 1 & & & \\
Mixed colors & & & & \\
Chalcedony & & & & & \\
\hline
\end{tabular}

Bagor (see Table 1). In addition, six chert types were identified in the artifact collection, but were not observed in the field. These "unidentified" chert types (chert types with unidentified sources) include: 1 red, 3 pinks, 1 gray striped, and 1 cream. A number of artifacts were made of cherts that were not easily categorized as one of the identified types. These artifacts were placed in the "unidentified" category, and a full set of raw material attributes was recorded for each.

The analysis demonstrated that approximately one-third of the Bagor chert artifacts strongly resembled the cherts found during field survey, and may have come from the region of study. This further suggests that the inhabitants of Bagor regularly traveled to the south and southeast, as far as $105 \mathrm{~km}$. However, the remaining two-thirds of 
the chert artifacts were made of unidentified chert, which shows that some sources utilized by the inhabitants of Bagor have not yet been located and that the inhabitants probably also traveled outside of the study area. Khanna (1988, 1992, 1993) suggests the Vindhyan Hills and Deccan Trap formations as possible sources.

After identifying the presence of non-local materials, a lot-by-lot comparison was made to see how the use of different regions may have shifted over time. During excavation, all artifacts collected in a given excavation level were grouped into "lots." Thus, a lot-by-lot comparison provided the opportunity to examine shifts in raw material use over time. As each level had been excavated to a slightly different depth, each lot had a slightly different soil volume. ${ }^{4}$ To counteract these differences, the artifacts per $\mathrm{m}^{2}$ were calculated for each lot. This enabled the lots to be easily compared. Raw materials were divided into four categories: local (quartz), southwest (Nathdwara chert), south/southeast and Deccan (all chalcedony and all cherts identified through field survey), and unknown source. The results are shown in Figure 3. As the lot numbers were assigned sequentially during excavation, lower lot numbers represent more recent time periods (e.g., 1006) and higher lot numbers represent older time periods (e.g., 1017).

In every lot local artifacts outnumber non-local artifacts. In addition, artifacts from unknown sources outnumber artifacts from the southeast and Deccan. Artifacts from the southwest represent the smallest portion of artifacts. The chart shows that the ratio of the different sources changes over time. In Lot 1006 the use of all materials declines, but the use of non-local materials declines more than local materials. The overall decline may indicate a decrease in population at the site, a reduction in activities that require stone tools, or the adoption of non-stone materials for cutting, scrap-

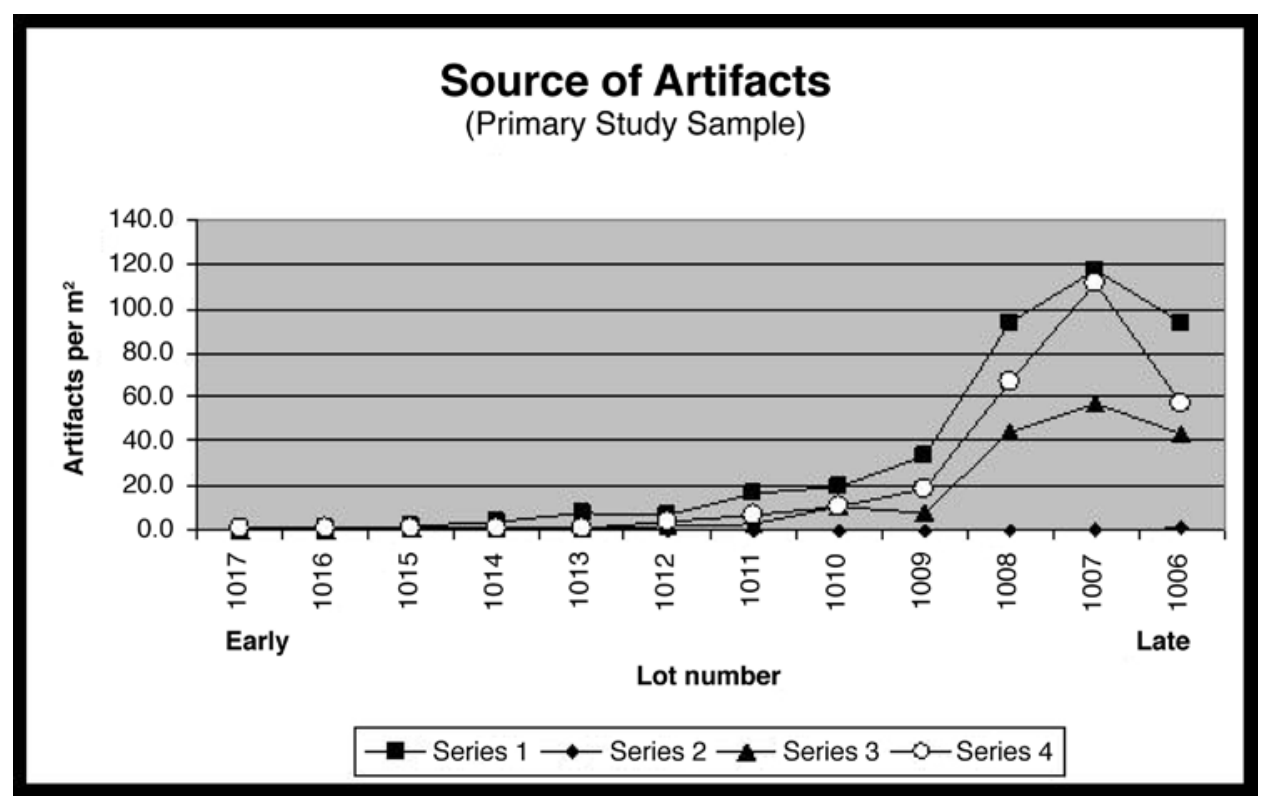

Fig. 3. Source of artifacts. 
ing, and piercing tasks. However, the decrease in use of non-local materials may indicate lower mobility levels in the later occupations at the site. In examining the non-local materials, it appears that in the early periods slightly more material from unknown sites is used compared to materials from known sites. However, in later periods (as represented by Lots 1008 and 1007), the use of materials from unknown sites increases, and then decreases dramatically in the final phases of occupation (as represented by Lot 1006). Lot 1007 was the only lot where chert artifacts outnumbered quartz artifacts, which affected this ratio. The shift in use of known versus unknown sites between Lots 1006, 1007, and 1008 indicates a parallel shift in mobility patterns to different regions during the time of those occupations. In sum, the range of mobility of the occupants of Bagor seems to have changed over time and was not consistent during all occupations. Such alterations in mobility may indicate changes in economic strategies or the ebb and flow of social networks centered in the south and the Deccan.

In order to contextualize the findings from Bagor, the raw material distribution was compared to that of the artifacts from Gilund, a large site of the Ahar-Banas complex (see Fig. 4). Gilund was a permanent settlement with both domestic and monumental architecture as well as an economy that combined agro-pastoralism and small-scale craft production (Dasgupta Ghosh 2010; Deshpande and Shinde 2006; IAR 1959-1960; Shinde and Possehl 2005; Shinde and Raczek 2010). Thousands of lithics were recovered during the recent excavations, and a sample of these was fully

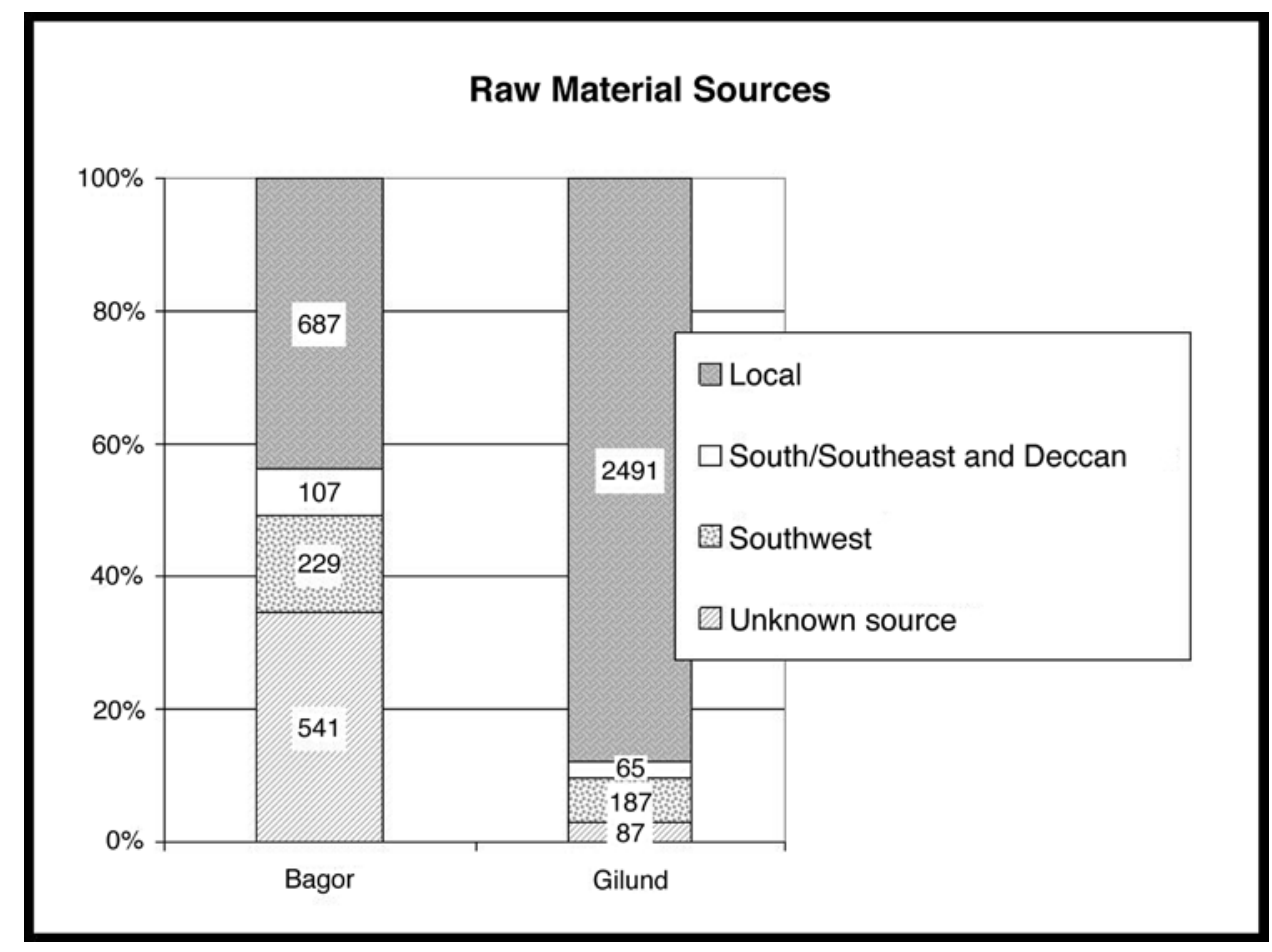

Fig. 4. Distribution of raw material sources at Gilund and Bagor. Bagor sample includes Lots 1006-1008. 
analyzed using the same methods as the Bagor analysis (Raczek 2007). Only Bagor lithics that were considered to be contemporaneous with Gilund (i.e., Bagor Lots 1006-1008) were selected for comparison.

The study shows that the distribution of raw material sources differs greatly between these two sites. First, Gilund utilized local raw materials much more heavily than Bagor. At Gilund, the primary raw material was quartz, and the use of cherts and chalcedonies was minimal. Second, while the majority of the Bagor chert artifacts came from an unknown source, the majority of the Gilund chert potentially came from one of four known sources. ${ }^{5}$ While the amount of chert is not sufficient to suggest organized trade in stone, the movement of chert may reflect either the mobility of some Gilund inhabitants or their exchange relationships with sites approximately 60-80 km to the southeast, or both. Third, more chert types were identified at Bagor than at Gilund, which had a more limited repertoire of cherts. This indicates that the inhabitants of Bagor used a greater variety of sources compared to Gilund. This may be explained in part by their greater mobility, which would potentially allow them greater access to more raw material sources. Overall, the two collections appear to be quite distinct and meet expectations for the levels of mobility previously hypothesized for each site.

\section{DISCUSSION AND CONCLUSION}

It has long been thought that the occupants of the site of Bagor practiced a mobile lifestyle. Ethnographic studies in Rajasthan and throughout South Asia suggest that mobility complements a number of economic strategies, including hunting and gathering, pastoralism, craft production, and service provision. While the full range of economic activities undertaken by the occupants of Bagor is not yet understood, the faunal analysis suggests that pastoralism featured prominently. Contemporary pastoralists in the region have traveled seasonally in all directions, particularly to the south and west to Gujarat. These journeys vary in time and distance depending on the strength and length of the annual monsoon. Such considerations would have also been important for pastoral activities during the time under investigation.

In addition to environmental considerations, social factors influence decisions about where and when to travel. Disruptions in social relations between migratory groups and those who own the land on which they camp can significantly alter longstanding routes. Additionally, the creation of social ties in new regions can also encourage the development of new routes and the discontinuing of old ones. Such ties may reflect growing political alliances or disputes. They may also reflect economic relationships brought about by the consumption of new craft materials like copper. Such factors would have been particularly important if the occupants of Bagor were transhumant and integrated into a sedentary village for much of the year. At sedentary sites in the Mewar plain, full-time specialized craft production using non-local materials increased over the expanse of the third millennium B.C. As artisans sought new materials, they engaged in new relationships with new regions. The remains of those who traveled in between reflect these changes.

Previous archaeological research on artifact typologies identified interaction between Bagor and sites in southeastern Rajasthan and beyond. Analyses of lithic production techniques supported these finds (Raczek 2010a). However, with the 
exception of Khanna's raw material study, a study of the range and direction of mobility had not yet been attempted. In order to detect the directions of movement of the past inhabitants of Bagor, this study investigated the sources of raw materials used for producing microliths and other lithic tools. Toward this end a targeted survey of potential chert and chalcedony sources was conducted. This was followed by visual analysis of raw material samples and lithics from Bagor. Paired with ethnographic research and the study of other classes of artifacts, raw material analysis provides a strong third leg for discerning mobility patterns and trajectories.

Through the field survey, five potential chert sources for the inhabitants of Gilund and Bagor were identified, including Semara, Nathdwara, Bhagwanpura, Chitoriya, and Berugati. While Nathdwara had a distinct chert conglomerate, different varieties of red, yellow, cream, blue-gray, and black cherts were available at all of the remaining sources except for Bhagwanpura, which had a bluish-black translucent chert. In addition, chalcedony was found at Semara. The Banas River was also identified as a secondary source for the Nathdwara chert. Evidence of microblade and microlith production was identified at all of the sources except for Nathdwara, which had considerable modern disturbance. Thus, although Bagor relied heavily on local materials, the occupants also used materials that came from over $100 \mathrm{~km}$ away. In addition, many of the sources remain unidentified. As all of the deposits were small and localized, most non-local material seems to have been obtained either sporadically or incidentally; there does not seem to be a system of organized procurement as in the Indus.

The study demonstrates that the inhabitants of Bagor were quite mobile; they traveled through a large landscape and collected from multiple chert and chalcedony sources. Mobility created the opportunity for the occupants of Bagor to engage in exchange with multiple communities within this region. Exchange provides a secondary method of obtaining lithic materials. The wide variety of cherts in their assemblage reflects this broad movement and the social relations that were enabled by it. The identified sources still lie within the broader region in which the Ahar-Banas white-painted black and red ware pottery is found. That is, evidence suggests that the occupants of Bagor traveled within the area known as the Ahar-Banas Cultural Complex. As travelers between the nodes of social networks, the occupants of Bagor were situated in a unique position and perhaps served as ties that brought distant sites together. As they traversed between settlements, they had the opportunity to carry news, messages, and goods between sites.

Because the survey conducted as part of this study was limited in scope, it was not possible to identify all potential chert sources of Bagor. The areas traversed by the occupants of Bagor likely extended outside the study area, and potentially included areas in northeastern Madhya Pradesh, northern Gujarat, and northern Rajasthan (i.e., the Ganeshwar-Jodhpura region and beyond). The direction and intensity of mobility appear to have shifted over time, with a general decrease in movement in the latest phases of occupation. The change in regions traversed may have been precipitated by the adoption of new occupations and new economic strategies (such as the pursuit of other raw materials), or a de-emphasis on pastoralism. Alternatively, it also could indicate shifts in the social composition of the region, a disintegration of older social networks and the creation of new ones, or changing regional power dynamics. The decrease in non-local materials indexes lower levels of mobility or a shrinking of previous ranges in response to shifting economic practices (including the possible 
adoption of seasonal crop cultivation, which would limit mobility considerably) or social factors as outlined above.

The raw material analysis showed a significant difference in the distribution of raw materials between Bagor and a contemporaneous collection from the permanent farming settlement of Gilund. It is clear that the residents at Gilund relied much more heavily on locally available materials and rarely used non-local materials. When they did use non-local materials, they used a narrower range of cherts, compared to Bagor, which used a great variety of cherts. In fact, while the majority of Gilund chert appears to have come from one of four sources identified through the field survey, this is not true for Bagor. In sum, these three differences between Gilund and Bagor support the idea that the occupants of Bagor were much more mobile than those of Gilund. The material landscape of Bagor is potentially much larger than that of Gilund.

The study of mobility in and of itself is an important one for considering the nature of regional and long-distance networks as well as dispersed communities and social identities. The inhabitants of Bagor clearly had a geographically wide-ranging network and may have served to bridge the communication gap between large areas. In addition, they had the opportunity to connect communities that were dispersed over wide regions. While the extent to which they were integrated into existing polities is uncertain, their position as a community that straddled regions was potentially a fruitful one and full of potential. Of course, excavation of additional contemporary mobile sites in the region will help to fill in this picture.

\section{ACKNOWLEDGMENTS}

I am grateful to the Archaeological Survey of India, Vasant Shinde, and Gregory L. Possehl for granting permission to study the collections from Bagor and Gilund and conduct research in India. Funding for this research was provided by the William J. Fulbright Association and the Zwicker Fund at the University of Pennsylvania; logistical help was provided by the American Institute for Indian Studies. At Deccan College, Prabodh Shirvalkar kindly offered assistance and Prof. V. N. Misra answered critical questions about the Bagor lithics. Helpful comments on early drafts of this article were provided by Gregory L. Possehl, Matthew J. Landt, Namita Sugandhi, and three anonymous reviewers. Shortcomings remain mine alone.

\section{ENDNOTES}

1. I am grateful for the advice offered by several geologists who were consulted for their opinions, including Dr. R. A. Sharma, Senior Geologist at the Geological Survey of India, Rajasthan; Dr. Chauhan at the Department of Geology, Udaipur (an independent university); and Dr. G. L. Vyas, the Director of the Rajasthan Department of Mines and Geology, Udaipur. They agreed that very little chert was to be found in the region, but that most of it was likely to be found in scattered deposits to the southeast, near the border with the state of Madhya Pradesh.

2. Only successful identifications are presented; other locales were explored, including areas in the Jahazpur range, and limestone deposits in the $25 \mathrm{~km}^{2}$ area around the site of Gilund. However, none of these met sufficient criteria to be considered a source and they are therefore not included here.

3. Garnet occurs locally in southeastern Rajasthan and can be found as small nodules in the soil around the sites of Gilund and Bagor. Farmers commented that they find garnet regularly during plowing, and Leshnik (1968) comments that he encountered worked garnet in his surveys. Garnet is quite difficult to knap, and instances of worked garnet as beads, pendants, or tools at prehistoric sites are quite rare. However, as the hardness for garnet ranges from 6.5 to 8.5 , it is possible to knap some garnets. In my experiments, I successfully removed several pressure flakes from locally procured raw garnet with both antler and copper punches. Eight pieces of garnet were identified in the Bagor collection: five com- 
plete flakes, one complete blade, one proximal flake, and one proximal blade. Each of these pieces had a clear bulb and rings of percussion. Five of these had distinct dorsal ridges while three had unworked dorsal faces. They were generally quite small, compared to the other materials, most likely because the material occurs in very small nodules.

4. Excavation episodes were $5 \mathrm{~cm}$ arbitrary levels unless a new context was encountered, in which case the episode may represent less than 5 vertical $\mathrm{cm}$.

5. The difference here is significant (Chi-square $=127.2833, \mathrm{df}=1, \mathrm{p}<=0.001)$.

\section{REFERENCES CITED}

AdAms, Robert McC.

1974 The Mesopotamian social landscape: A view from the frontier, in Reconstructing Complex Societies: An Archaeological Colloquium: 1-20, ed. Charlotte Moore. Cambridge: American Schools of Oriental Research.

Ajithprasad, P.

2002 The Pre-Harappan cultures of Gujarat, in Protohistory: Archaeology of the Harappan Civilization: 129-158, ed. S. Settar and R. Korisettar. Indian Archaeology in Retrospect, vol. II. New Delhi: Indian Council of Historical Research and Manohar.

Alizadeh, AbBas

2009 Prehistoric mobile pastoralists in south-central and southwestern Iran, in Nomads, Tribes, and the State in the Ancient Near East: Cross-Disciplinary Perspectives: 129-145, ed. Jeffrey Szuchman. Oriental Institute Seminars Number 5. Chicago: Oriental Institute of the University of Chicago.

Allchin, Bridget

1977 Hunters, pastoralists and early agriculturalists in South Asia, in Hunters, Gatherers and First Farmers Beyond Europe: 127-143, ed. J.V.S. Megaw. Leicester: Leicester University Press.

1985 Ethno-archaeology in South Asia, in South Asian Archaeology 1983:21-33, ed. J. Schotsmans and M. Taddei. Naples: Istituto Universitario Orientale.

ANDREFSKy, William, JR.

1994 Raw-material availability and the organization of technology. American Antiquity 59(1):21-35.

ASCHER, RichARD

1961 Analogy in archaeological interpretation. Southwestern Journal of Anthropology 17:317-325.

BAyMAN, JAMES M.

2003 Stone adze economies in post-contact Hawai'i, in Stone Tool Traditions in the Contact Era: 94108, ed. Charles Cobb. Tuscaloosa: University of Alabama Press.

Bhan, Kuldeep K.

1994 Cultural development of the Prehistoric period in north Gujarat with reference to western India. South Asian Studies 10:71-90.

2011 Pastoralism in Late Harappan Gujarat, western India: An ethnoarchaeological approach, in Linguistics, Archaeology and the Human Past: 1-26, ed. Toshiki Osada and Akinori Uesugi, Occasional Paper 10. Kyoto: Indus Project, Research Institute for Humanity and Nature.

Bhan, Kuldeep K., M. Vidale, and Jonathan M. Kenoyer

2002 Some important aspects of the Harappan technological tradition, in Protohistory: Archaeology of the Harappan Civilization: 223-271, ed. S. Settar and Ravi Korisettar. Indian Archaeology in Retrospect, volume II. Delhi: Manohar.

Biagi, Paolo, and Mauro Cremaschi

1990 Geoarchaeological investigations on the Rohri Hills (Sind, Pakistan), in South Asian Archaeology 1987:31-42, ed. M. Taddei and P. Callieri. Rome: IsMEO.

BINFORD, LEWIS R.

1979 Organization and formation processes: Looking at curated technologies. Journal of Anthropological Research $35: 255-273$.

1980 Willow smoke and dog's tails: Hunter-gatherer settlement systems and archaeological site formation. American Antiquity 45:4-20.

Brantingham, P. Jefrerey, John W. Olsen, Jason A. Rech, and Andrei I. Krivoshapkin

2000 Raw material quality and prepared core technologies in northeast Asia. Journal of Archaeological Science 27(3) : 255-271. 
Carmody, Michael

2003 A functional analysis of the Cameron Site chipped-stone assemblage, in Stone Tool Traditions in the Contact Era: 59-77, ed. Charles Cobb. Tuscaloosa: University of Alabama Press.

Chase, Bradley A.

2004 Ethno-archaeology in South Asia: An introduction and review, in Archaeology as History in Early South Asia: 280-301, ed. Himanshu Prabha Ray and Carla M. Sinopoli. New Delhi: Indian Council of Historical Research and Aryan Books International.

Childers, C. H.

1975 Banjaras, in Pastoralists and Nomads in South Asia: 247-265, ed. L. S. Leshnik and G. D. Sontheimer. Weisbaden: Otto Harrassowitz.

2003 Banjaras, in Nomadism in South Asia: 398-418, ed. Aparna Rao and Michael J. Casimir. New Delhi: Oxford University Press.

Close, Angela E.

2000 Reconstructing Movement in Prehistory. Journal of Archaeological Method and Theory 7:49-77.

Clutton-Brock, Juliet

1965 Excavations at Langhnaj: 1944-63; Part II: The Fauna. Pune: Deccan College Postgraduate and Research Institute.

COOPER, ZARINE

1997 Prehistory of the Chitrakot Falls, Central India. Pune: Ravish Publishers.

Dasgupta Ghosh, Debashri

2010 An insight into the economy of the Chalcolithic people of Gilund, in The Gilund Project: Excavations in Regional Context. Proceedings of the 19th International Conference on South Asian Archaeology, July 2007, Ravenna, Italy: 31-34, ed. Teresa P. Raczek and Vasant Shinde. South Asian Archaeology 2007 Special Sessions 2. Oxford: British Archaeological Reports.

Deshrande, S. S., and Vasant Shinde

2006 Development of Urbanization in the Mewar Region of Rajasthan, India in the Middle of the Third Millennium B.c. Ancient Asia $1: 103-122$.

Dibble, Harold L.

1991 Local raw material exploitation and its effects on Lower and Middle Paleolithic assemblage variability, in Raw Material Economies among Prehistoric Hunter-Gatherers: 33-48, ed. A. MontetWhite and S. Holden. University of Kansas Publications in Anthropology 19. Lawrence: University of Kansas Publications.

DUTT, BAHAR

2004 Livelihood strategies of a nomadic hunting community of eastern Rajasthan. Nomadic Peoples $8(2): 260-273$.

Ehrhardt, Sophie, and Kenneth A. R. Kennedy

1965 Excavations at Langhnaj: 1944-63; Part III: The Human Remains. Pune: Deccan College Postgraduate and Research Institute.

Fisher, R. J.

1997 If Rain Doesn't Come: An Anthropological Study of Drought and Human Ecology in Western Rajasthan. New Delhi: Manohar.

Fox, R. G.

1969 Professional primitives: Hunters and gatherers of nuclear South Asia. Man in India 49(2):139-160.

Geneste, JeAn-Michel

1985 Analyse Lithique d'Industries Moustériennes du Périgord: Une Approche Technologique du Comportement des Groupes Humains au Paléolithique Moyen. Bordeaux: Université de Bordeaux I.

Gould, Richard A., and S. Saggers

1985 Lithic procurement in central Australia: A closer look at Binford's idea of embeddedness in archaeology. American Antiquity 50(1):117-136.

Gould, Richard A., and Patty Jo Watson

1982 A dialogue on the meaning and use of analogy in ethnoarchaeological reasoning. Journal of Anthropological Archaeology 1:355-381.

GuHA, SudeshnA

1994 Recognising "Harappan": A critical review of the position of hunter-gatherers within Harappan society. South Asian Studies 10:91-97. 
Gupta, S. N., Y. K. Arora, R. K. Mathur, Iqbaluddin, Balmiki Prasad, T. N. Sahai, and S. B. SHARMA

1997 The Precambrian Geology of the Aravalli Region, Southern Rajasthan, and Northeast Gujarat. Jaipur: Government of India.

Hayden, Robert M.

1987 Conflicts and relations of power between peripatetics and villagers in South Asia, in The Other Nomads: Peripatetic Minorities in Cross-Cultural Perspective: 267-290, ed. A. Rao. Koln: Bohlau Verlag Koln Wien.

Helms, Mary

1993 Craft and Kingly Ideal: Art, Trade, and Power. Austin: University of Texas Press.

Hockings, Paul, ED.

1989 Blue Mountains: The Ethnography and Biogeography of a South Indian Region. New Delhi: Oxford University Press.

Hooja, Rima

1988 The Ahar Culture and Beyond: Settlements and Frontiers of "Mesolithic" and Early Agricultural Sites in South-Eastern Rajasthan, c. 3rd-2nd Millennia B.C. Oxford: British Archaeological Reports International Series 412.

1994 Contacts, conflicts and coexistence: Bhils and non-Bhils in southeastern Rajasthan, in Living Traditions: Studies in the Ethnoarchaeology of South Asia: 125-142, ed. Bridget Allchin. Delhi: Oxford \& IBH.

Indian ArChaeology, A Review (IAR)

1953- Excavations at Langhnaj. Delhi: Archaeological Survey of India.

1954

1959- Excavations at Gilund. Delhi: Archaeological Survey of India.

1960

1963- Excavations at Langhnaj. Delhi: Archaeological Survey of India.

1964

1967- Excavations at Bagor. Delhi: Archaeological Survey of India.

1968

1968- Excavations at Bagor. Delhi: Archaeological Survey of India.

1969

1969- Excavations at Bagor. Delhi: Archaeological Survey of India.

1970

JACOBSON, Jerome

1975 Static sites and peripatetic peoples: Notes on the archaeology of population mobility in Eastern Malwa, in Pastoralists and Nomads in South Asia: 68-91, ed. Lawrence S. Leshnik and G. D. Sontheimer. Wiesbaden: Otto Harrassowitz.

Jarrige, Catherine, Jean-François Jarrige, Richard H. Meadow, and G. Quivron

1995 Mehrgarh: Field Reports 1974-1985, from Neolithic Times to the Indus Civilization. Karachi: Department of Culture and Tourism of Sindh, Pakistan, Department of Archaeology and Museums, French Ministry of Foreign Affairs.

Jarrige, Jean-François, Catherine Jarrige, and G. Quivron

2005 Mehrgarh Neolithic: The updated sequence, in South Asian Archaeology 2001, vol. 1: Prehistory: 128-141, ed. Catherine Jarrige and Vincent Lefevre. Paris: Éditions Recherche sur les Civilisations.

JOHNSON, JAY K.

1997 Stone tools, politics, and the eighteenth-century Chickasaw in Northeast Mississippi. American Antiquity 62(2): 215-230.

Karve, Irawati, and G. M. Kurulkar

1945 Human Remains Discovered So Far: A Preliminary Report on the Human Skeletal Remains Found at Langhnaj in February and December 1944. Poona: Deccan College.

Karve-Corvinus, Gudrun, and Kenneth A. R. Kennedy

1964 Preliminary report on Langhnaj excavation-1963. Bulletin of the Deccan College Research Institute $24: 44-57$.

Kashyap, Arunima

2006 Use-Wear and Starch Grain Analysis: An Integrated Approach to Understanding the Transition from Hunting and Gathering to Food Production at Bagor, Rajasthan, India. Ph.D. diss. Michigan State University, East Lansing, Michigan. 
Kavoori, Purnendu S.

1999 Pastoralism in Expansion. New Delhi: Oxford University Press.

KeLly, RoBert L.

1992 Mobility/sedentism: Concepts, archaeological measures, and effects. Annual Review of Anthropology $21: 43-66$.

Kennedy, Kenneth A. R.

1982 Biological anthropology of human skeletal remains from Bagor: Osteology, in Bagor and Tilwara: Late Mesolithic Cultures of Northwest India, vol. I: The Human Skeletal Remains: 27-51, ed. John R. Lukacs, V. N. Misra and Kenneth A. R. Kennedy. Pune: Deccan College Postgraduate and Research Institute.

KenOyer, Jonathan M.

1991 Contemporary stone bead making in Kambhat India. World Archaeology 23(1) : 44-63.

Khanna, Gurcharan Singh

1988 Reassessing the Mesolithic of India: With Special Reference to the Site of Bagor, Rajasthan. Ph.D. diss. University of California, Berkeley.

1992 Patterns of mobility in the Mesolithic of Rajasthan, in South Asian Archaeology 1989:153-159, ed. Catherine Jarrige, John P. Gerry, and Richard H. Meadow. Monographs in World Archaeology no. 14. Madison: Prehistory Press.

1993 Patterns of mobility in the Mesolithic of Rajasthan. Man and Environment 18(1):49-55.

Khazanov, Anatoly

2009 Specific characteristics of Chalcolithic and Bronze Age pastoralism, in Nomads, Tribes, and the State in the Ancient Near East: Cross-Disciplinary Perspectives: 119-127, ed. Jeffrey Szuchman. Oriental Institute Seminars Number 5. Chicago: Oriental Institute of the University of Chicago.

Kuhn, Steven L.

1994 A formal approach to the design and assembly of mobile toolkits. American Antiquity $59(3): 426-442$.

Kumar, S., and Purnima Srivastava

1992 Microfossils from the black chert of Bhagwanpura Limestone (Middle Proterozoic), Vindhyan Supergroup, Chittorgarh area, Rajasthan, West India. Current Science 62(4) :371-372.

Kumar, ViJay

1970- Disposal of the dead in ancient Bagor. The Researcher 10-13:53-58.

1973

LAW, RANDALL

2005a A diachronic examination of lithic exchange networks during the Urban Transformation of Harappa, in South Asian Archaeology 2003:111-122, ed. Ute Franke-Vogt and H.-J. Weisshaar. Bonn: Kommission für Allgemeine und Vergleichende Archäologie.

2005 begional interaction in the prehistoric Indus Valley: Initial results of rock and mineral sourcing studies at Harappa, in South Asian Archaeology 2001:179-190, ed. Catherine Jarrige and Vincent Lefevvre. Paris: Musée National des Arts Asiatiques Guimet.

Law, Randall, and Syed Rafiqul Hassan BaqRi

2003 Black chert source identified at Nammal Gorge, Salt Range. Ancient Pakistan 14:34-40.

LESHNIK, LAWRENCE S.

1968 Prehistoric exploration in north Gujarat and parts of Rajasthan. East and West 18:295-310.

1972 Pastoral nomadism in the archaeology of India and Pakistan. World Archaeology 4(2):150166.

1974 More microliths from Gujarat and some thoughts on Langhnaj, in Perspectives in Palaeoanthropology: Professor D. Sen Festschrift: 249-258, ed. Ashok K. Ghosh. Calcutta: Firma K. L. Mukhopadhyay.

LuedtKe, Barbara E.

1992 An Archaeologist's Guide to Chert and Flint. Los Angeles: Institute of Archaeology, University of California.

Lukacs, John R.

1982 Biological anthropology of human skeletal remains from Bagor: Dentition, in Bagor and Tilwara: Late Mesolithic Cultures of Northwest India, vol. I: The Human Skeletal Remains: 61-85, ed. John R. Lukacs, V. N. Misra, and Kenneth A. R. Kennedy. Pune: Deccan College Postgraduate and Research Institute. 
1990 On hunter-gatherers and their neighbors in prehistoric India: Contact and pathology. Current Anthropology 31(2) : 183-186.

Madella, M., P. Ajithprasad, C. Lancelotti, B. Rondelli, A. Balbo, C. French, D. Rodriguez, J. J. Garcia-Granero, V. Yannitto, S. V. Rajesh, C. S. Gadekar, and I. Briz

2010 Social and environmental transitions in arid zones: the North Gujarat Archaelogical ProjectNoGAP. Antiquity 84(325).

Marks, A. E., J. Shokler, AND J. Zilhão

1991 Raw material usage in the Paleolithic. The effects of local availability on selection and economy, in Raw Material Economies Among Prehistoric Hunter-Gatherers: 127-139, ed. A. MontetWhite and S. Holen. University of Kansas Publications in Anthropology 19. Lawrence: University of Kansas Publications.

Meadow, Richard H., and Ajita K. Patel

2002 From Mehrgarh to Harappa and Dholavira: Prehistoric pastoralism in north-western South Asia through the Harappan Period, in Protohistory: Archaeology of the Harappan Civilization: 391-408, ed. S. Settar and Ravi Korisettar. Indian Archaeology in Retrospect. New Delhi: Indian Council of Historical Research and Manohar.

MisRa, P. K.

1975 The Gadulia Lohars. In Pastoralists and Nomads in South Asia: 235-246, ed. Lawrence S. Leshnik and G. D. Sontheimer. Wiesbaden: Otto Harrassowitz.

1977 The Nomadic Gadulia Lohar of Eastern Rajasthan. Calcutta: Anthropological Survey of India, Government of India.

MisRa, V. N.

1967 Pre- and Proto-History of the Berach Basin South Rajasthan. Poona: Deccan College Postgraduate and Research Institute.

1970 Cultural significance of three copper arrow-heads from Rajasthan India. Journal of Near Eastern Studies 29(4) : 221-231.

1971 Two microlithic sites in Rajasthan-a preliminary investigation. The Eastern Anthropologist 24(3) : 237-288.

1972 Burials from prehistoric Bagor, Rajasthan, in Archaeological Congress and Seminar Papers: 58-65, ed. S. B. Deo. Nagpur: Nagpur University.

1973 Bagor: A late Mesolithic settlement in north-west India. World Archaeology 5(1): 92-100.

1982 Bagor: The archaeological setting, in Bagor and Tilwara: Late Mesolithic Cultures of Northwest India, vol. I: The Human Skeletal Remains: 9-20, ed. John R. Lukacs, V. N. Misra, and Kenneth A. R. Kennedy. Pune: Deccan College Postgraduate and Research Institute.

1990 The Van Vagris — "lost" hunters of the Thar Desert, Rajasthan. Man and Environment 15(2) : 89108.

Mohanty, Pradeep, and Jitu Mishra

2002 Fifty years of ethno-archaeological research in India: A review, in Archaeology and Interactive Disciplines: 269-308, ed. S. Settar and Ravi Korisettar. Indian Archaeology in Retrospect. New Delhi: Manohar.

Morrison, KathleEN D.

$2002 a$ Historicizing adaptation, adapting to history: Forager-traders in South and Southeast Asia, in Forager-Traders in South and Southeast Asia: Long Term Histories: 2-17, ed. Kathleen D. Morrison and Laura L. Junker. Cambridge: Cambridge University Press.

$2002 b$ Pepper in the hills: Upland-lowland exchange and the intensification of the spice trade, in Forager-Traders in South and Southeast Asia: Long Term Histories: 105-128, ed. Kathleen D. Morrison and Laura L. Junker. Cambridge: Cambridge University Press.

2002 c South Asia: Introduction, in Forager-Traders in South and Southeast Asia: Long Term Histories: 21-40, ed. Kathleen D. Morrison and Laura L. Junker. Cambridge: Cambridge University Press.

Mughal, M. Rafique

1994 The Harappan nomads of Cholistan, in Living Traditions: Studies in the Ethnoarchaeology of South Asia: 53-68, ed. Bridget Allchin. Delhi: Oxford \& IBH.

Murty, M.L.K.

1994 Forest peoples and historical traditions in the Eastern Ghats, south India, in Living Traditions: Studies in the Ethnoarchaeology of South Asia: 205-218, ed. Bridget Allchin. Delhi: Oxford \& IBH.

Nagar, Malti, and V. N. Misra

1990 The Kanjars - a hunting-gathering community of the Ganga Valley, Uttar Pradesh. Man and Environment 15(2): 71-88. 
NeLson, Cynthia

1973 The Desert and the Sown: Nomads in the Wider Society. Berkeley: University of California Press.

Odell, George H.

2003 Wichita tools on first contact with the French, in Stone Tool Traditions in the Contact Era: 29-50, ed. Charles R. Cobb. Tuscaloosa and London: University of Alabama Press.

Panja, SheEna

1996 Mobility strategies, site structure and settlement organization: An actualistic perspective. Man and Environment 21(1): 74-85.

1999 Mobility and subsistence strategies: A case study of Inamgaon, a Chalcolithic site in Western India. Asian Perspectives 38(2): 154-185.

Patel, Ajita K.

2009 Occupational histories, settlements, and subsistence in Western India: What bones and genes can tell us about the origins and spread of pastoralism. Anthropozoologica 44(1):173-188.

Peterson, Jean Treloggen

1978 Hunter-gatherer/farmer exchange. American Anthropologist 80(2):335-351.

Possehl, Gregory L.

1976 Lothal: A gateway settlement of the Harappan Civilization, in Ecological Backgrounds of South Asian Prehistory: 118-131, ed. Kenneth A. R. Kennedy and Gregory L. Possehl. Ithaca: Cornell University South Asia Program, Occasional Papers and Theses, No. 4.

1979 Pastoral nomadism in the Indus Civilization: An hypothesis, in South Asian Archaeology 1977:537-551, ed. M. Taddei. Naples: Instituto Universitario Orientale, Seminario di Studi Asiatici, Series Minor 6.

1982 Cambay bead-making: An ancient craft in modern India. Expedition 23(4):39-46.

1993 The Harappan Civilization and its hunter-gatherer neighbors. Vestnik Drevni Istorii 4(207) : 119-127.

2002 Harappans and hunters: Economic interaction and specialization in prehistoric India, in Forager-Traders in South and Southeast Asia: Long Term Histories: 62-76, ed. Kathleen D. Morrison and Laura L. Junker. Cambridge: Cambridge University Press.

2007 The Harappan settlement of Gujarat, in Settlement and Society: Essays Dedicated to Robert McCormick Adams: 297-328, ed. Elizabeth C. Stone. Los Angeles and Chicago: Cotsen Institute of Archaeology and Oriental Institute of the University of Chicago.

Possehl, Gregory L., and Kenneth A. R. Kennedy

1979 Hunter-gatherer/agriculturalist exchange in prehistory: An Indian example. Current Anthropology 20(3): 592-593.

RACZEK, Teresa P.

2007 Shared Histories: Technology and Community at Gilund and Bagor, Rajasthan, India (c. 3000-1700 BC). Ph.D. diss. University of Pennsylvania, Philadelphia.

2010a Contextualizing Gilund: A Comparative Analysis of Technology, in The Gilund Project: Excavations in Regional Context. Proceedings of the 19th International Conference on South Asian Archaeology, July 2007, Ravenna, Italy: 35-42, ed. Teresa P. Raczek and Vasant Shinde. South Asian Archaeology 2007 Special Sessions 2. Oxford: British Archaeological Reports.

$2010 b$ In the context of copper: Indian lithics in the third millennium BC, in Lithic Technology in Metal Using Societies: 187-201, ed. Berit Valentin Eriksen. Proceedings of a UISPP Workshop, September 2006. Højbjerg: Jutland Archaeological Society.

Rao, Aparna

1987 The concept of peripatetics: An introduction, in The Other Nomads: Peripatetic Minorities in Cross-Cultural Perspective: 1-34, ed. Aparna Rao. Koln: Bohlau Verlag Koln Wien.

RAO, S. R.

1979 Lothal: A Harappan Port Town, 1955-62. Delhi: Archaeological Survey of India.

Rissman, Paul C., and Y. M. Chitalwala

1990 Harappan Civilization and Oriyo Timbo. Delhi: Oxford \& IBH and the American Institute of Indian Studies.

Rizvi, Uzma Z.

2010 Indices of interaction: Comparisons between the Ahar-Banas and Ganeshwar Jodhpura Cultural Complex, in The Gilund Project: Excavations in Regional Context. Proceedings of the 19th International Conference on South Asian Archaeology, July 2007, Ravenna, Italy: 51-61, ed. Teresa P. Raczek and Vasant Shinde. South Asian Archaeology 2007 Special Sessions 2. Oxford: British Archaeological Reports. 
Robbins, Gwen, V. Mushrif, V. N. Misra, R. K. Mohanty, and V. S. Shinde

2007 Adult skeletal material from Balathal: A full report and inventory. Man and Environment $32(2): 1-26$.

Rosen, STEven A.

1984 The Adoption of metallurgy in the Levant: A lithic perspective. Current Anthropology 25(4): 504-505.

1996 The decline and fall of flint, in Stone Tools: Theoretical Insights into Human Prehistory: 129-158, ed. George H. Odell. Interdisciplinary Contributions to Archaeology. New York: Plenum Press.

1997 Lithics after the Stone Age: A Handbook of Stone Tools from the Levant. Walnut Creek, CA: Altamira.

Roux, Valentine, And Jacques Pelegrin

1988- Knapping technique and craft specialization: An ethnoarchaeological investigation in Gujarat. 1989 Puratattva 19:50-59.

ROY, A. B., AND S. R. JAKHAR

2002 Geology of Rajasthan (Northwest India): Precambrian to Recent. Jodhpur: Scientific Publishers (India).

Sankalia, Hasmukh Dhirajlai

1955 Excavations at Langhnaj, Gujarat. Man 55:28.

1956 Nathdwara, a Palaeolithic site in Rajputana. Journal of the Palaeontological Society of India 1:99100.

1965 Excavations at Langhnaj: 1944-63, Part 1: Archaeology. Poona: Deccan College Postgraduate and Research Institute.

Selvakumar, V.

2002 Hunter-gatherer adaptations in Madurai Region, Tamil Nadu, India: From c. 10,000 B.P. to C. A.D. 500. Asian Perspectives 41(1): 71-102.

SHINDE, VASANT

2010 Development from Mesolithic to Chalcolithic in the Mewar Region of Rajasthan: Contribution of Gilund Excavation, in The Gilund Project: Excavations in Regional Context Proceedings of the 19th International Conference on South Asian Archaeology, July 2007, Ravenna, Italy: 7-12, ed. Teresa P. Raczek andVasant Shinde. South Asian Archaeology 2007 Special Sessions 2. Oxford: British Archaeological Reports.

Shinde, Vasant, and Gregory L. Possehl

2005 Excavations at Gilund 2001-2003: The seal impressions and other finds, in South Asian Archaeology 2003: 155-165, ed. Ute Franke-Vogt and H.-J. Weisshar. Bonn: Kommission für Allgemeine und Vergleichende Archäologie.

Shinde, Vasant, and Teresa P. Raczek

2010 Introduction: A review of the Gilund excavations and related research, in The Gilund Project: Excavations in Regional Context. Proceedings of the 19th International Conference on South Asian Archaeology, July 2007, Ravenna, Italy: 1-6, ed. Teresa P. Raczek andVasant Shinde. South Asian Archaeology 2007 Special Sessions 2. Oxford: British Archaeological Reports.

Silliman, STEVen

2003 Using a rock in a hard place: Native American lithic practices in colonial California, in Stone Tool Traditions in the Contact Era: 127-150, ed. Charles R. Cobb. Tuscaloosa: University of Alabama Press.

Sinopoli, Carla M.

1991 Seeking the past through the present: Recent ethno-archaeological research in South Asia. Asian Perspectives 30(2): 177-192.

SONTHeimer, Gunther D.

1975 The Dhangars: A nomadic pastoral community in a developing agricultural environment, in Pastoralists and Nomads in South Asia: 139-170, ed. Lawrence S. Leshnik and Gunther D. Sontheimer. Wiesbaden: Otto Harrassowitz.

SPielmann, Katherine

1986 Interdependence among egalitarian societies. Journal of Anthropological Archaeology $5: 279-312$.

SwAYAm, S.

2006 Invisible People. Oxford: British Archaeological Reports.

Thomas, P. K.

1975 The role of animals in the food economy of the Mesolithic culture of Western and Central India, in Archaeozoological Studies: 322-328, ed. A. T. Clason. Amsterdam: North-Holland. 
1977 Archaeozoological Aspects of the Prehistoric Cultures of Western India. Ph.D. diss. Deccan College, Poona.

1984 The faunal background of the Chalcolithic culture of western India, in Animals and Archaeology, 3: Early Herders and Their Flocks: 355-362, ed. J. Clutton-Brock and C. Greigson. International Series, 202. Oxford: British Archaeological Reports.

VARMA, SUPRIYA

1991 Villages abandoned: The case for mobile pastoralism in post-Harappan Gujarat. Studies in History $7(2): 279-300$.

Walimbe, Subhash R., and Shaunak S. Kulkarni

1993 Biological Adaptations in Human Dentition: An Odontometric Study on Living and Archaeological Populations in India. Pune: Deccan College Post Graduate and Research Institute.

Wendrich, Willeke, and Hans Barnard

2008 The archaeology of mobility: Definitions and research approaches, in The Archaeology of Mobility: Old World and New World Nomadism: 1-21, ed. Hans Barnard and Willeke Wendrich. Cotsen Advanced Seminars 4. Los Angeles: Cotsen Institute of Archaeology, University of California.

Wylie, Alison

2002 The reaction against analogy, in Thinking from Things: Essays in the Philosophy of Archaeology: 136-153, ed. Alison Wylie. Berkeley: University of California Press.

Yellen, John, And Henry Harpending

1972 Hunter-gatherer populations and archaeological inference. World Archaeology 4(2) :244-253.

ZeUner, F. E.

1952 The microlithic industry of Langhnaj, Gujarat. Man 52(182) :129-131.

\begin{abstract}
Mobility is an important part of life for those who practice a variety of economic strategies including foraging, pastoralism, craft production, service provision, and performance. Studies of mobility can contribute to broader understandings of social networks, community formation, and social identity in South Asia during the first few millennia B.C., a time of early social complexity. Previous ethnographic and archaeological research in the region shows a range of ways that mobile people form relationships with those who are more settled. In contrast to research that studies mobile people through the lens of sedentism, this study examines mobility directly, by focusing on the direction, range, and patterns of movement of the people who inhabited the site of Bagor (c. 5500 B.C.-A.D. 200) in Rajasthan, India. For much of its occupation, Bagor was used as a temporary camp by people with a high degree of mobility and a broad range of subsistence strategies. Although the links between Bagor and nearby permanent settlements have been clearly demonstrated, the direction, extent, and range of their movements during different time periods was previously unknown. This study examines the lithic raw materials from the 2001 re-excavations conducted by Deccan College (Pune) and pairs those results with a new survey of stone material sources in the region. Visual raw material analysis of the Bagor lithics indicate that local materials outnumber non-local materials and that approximately one-third of the Bagor chert artifacts may have come from regions to the south and southeast. In later time periods the use of non-local materials declines, which may reflect corresponding shifts in mobility. A comparison of the raw material distribution with the artifacts from Gilund, a contemporary sedentary settlement, shows a difference between their uses of raw material. Gilund utilized more local materials, and fewer non-local materials than Bagor. KeYwords: mobility, lithics, Bagor, Ahar-Banas Complex, raw materials, Rajasthan.
\end{abstract}

